and the præopercular margin. The first anal ray corresponds to the fourth or fifth of the dorsal fin. Anal fin much higher than long. Brownish olive, with numerous dark greenish indistinct cross bands (in the male).

A single male specimen, 3 inches long, has been sent by J. Matthew Jones, Esq., from the Bermudas.

\title{
Mollienesia Jonesii.
}

\section{12 . A. 10 . L. lat. 29. L. transv. 9.}

Female. The height of the body is two sevenths or one fourth of the total length (without caudal), the length of the head one fourth. The diameter of the eye is rather shorter than the snout, one fourth of the length of the head, and one half of the width of the interorbital space. The length of the dorsal fin is one fourth of the distance between the eye and root of the caudal; it is much longer than high. Anal fin small, opposite to the middle of the dorsal. Lateral line none. Brownish, each scale with a deep-black hind margin; a black band between the eye and scapula; a round black spot on the upper half of the root of the caudal. Dorsal fin with two or three series of black spots; anal with a black line behind and along each ray; the other fins immaculate.

This species was discovered by T. M. Rymer Jones, Esq., in a volcanic lake, Alcohuaca, near Huamantla, in Mexico, 8000 feet above the level of the sea. Several specimens were presented by him to the British Museum : all are females; and the largest exceeds somewhat the length of 3 inches.

\section{XLVIII.-Final Note on Eozoon canadense. By William B. Carpenter, M.D., LL.D., F.R.S.}

To the Editors of the Annals and Magazine of Natural History.

\section{Gentlemen,}

As it is obviously impossible to carry on any discussion without some common basis of agreement, and as Profs. King: and Rowney have now made it clear that no such basis can exist between them and myself, it is not my intention to trouble you with any reply to their last Paper.

For (1) my opponents deduce, from their examination of a few specimens of a single Foraminiferal type, what they affirm to be "Foraminiferal impossibilities;" and (2) under the preconception thus formed they refuse to credit my statement of an objective fact, viz. the existence of an unmistakable "nummuline tubulation" in a specimen of Eozoon which they have not examined. 
On the other hand (1) a study of Foraminifera, now prolonged over nearly thirty years, having convinced me (as a like study has convinced others) that to no group in the whole Animal Kingdom is Prof. Huxley's phrase " There is no end to the possibilities of Nature " more applicable, I cannot give up this conviction at the bidding of the Galway Professors. Many of the new types I have myself described would, according to their doctrine, have been impossibilities "from a Foraminiferal point of view"*; and I have many more in my possession (as yet undescribed) which are equally unconformable to any types previously known.

Again (2), being fully conscious of my own fallibility, I should be quite ready to believe that I see the "nummuline tubulation "in my specimen of Eozoon with my mind's eye rather than with my bodily eye (as Dr. Martin Barry saw "spirals" everywhere), if I were to find other experienced Microscopists, after "comparison of actual specimens," disagreeing with me. But having submitted this specimen, with a section of a recent Nummuline shell (Cycloclypeus), to a score or so of competent observers $\dagger$, and having received their entire assent to the correctness of my description and of Mr. George West's delineation, I cannot surrender our unanimous conviction of this objective reality, because Profs. King and Rowney, who have not seen the specimen, consider it a "Foraminiferal impossibility."

As I should now no more think of attempting to convince the Galway " infallibles," than of trying to convert the Pope, I leave them in triumphant possession of the field. Your readers, perhaps, may claim the exercise of "private judgment" in the matter.

Your obedient servant,

William B. Carpenter.

London, Oct. 17, 1874.

* Thus, of the gigantic arenaceous Parkeria of the Cambridge Greensand, I had to say (Philos. Transact. 1869, p. 734) :- "The strongly marked dissimilarity between the fabric of Parkeria as now described, and that of any Foraminifera previously known, whether recent or fossil, renders it impossible to predicate with certainty what was the precise relation of the animal to its arenaceous 'test.'" And yet I was able to append in a note, as that Paper was passing through the press :- "Since the above was written, I have obtained from the Deep-sea Dredgings of the 'Porcupine Expedition' (1869) a complete confirmation of the view taken in the text. For on examining the internal structure of the largest Nautiloid Lituole, I find, though in a rudimentary condition, a labyrinthic structure whose relation to the chamber it surrounds is essentially the same as in Parkeria."

$\dagger$ As Profs. King and Rowney may possibly give the credit to the impartial attestation of their own colleagues and friends, which they refuse to my statements, I would refer them to Prof. Cleland of Galway, Prof. Redfern of Belfast, Prof. Greene of Cork, and Prof. Perceval Wright, Dr. Macalister, and Mr. Archer of Dublin. 


\section{$2 \mathrm{BHL}$ Biodiversity Heritage Library}

Carpenter, William Benjamin. 1874. "XLVIII.-Final note on Eozoon canadense." The Annals and magazine of natural history; zoology, botany, and geology 14, 371-372. https://doi.org/10.1080/00222937408680988.

View This Item Online: $\underline{\text { https://www.biodiversitylibrary.org/item/63340 }}$

DOI: https://doi.org/10.1080/00222937408680988

Permalink: https://www.biodiversitylibrary.org/partpdf/58769

\section{Holding Institution}

University of Toronto - Gerstein Science Information Centre

\section{Sponsored by}

University of Toronto

\section{Copyright \& Reuse}

Copyright Status: NOT_IN_COPYRIGHT

This document was created from content at the Biodiversity Heritage Library, the world's largest open access digital library for biodiversity literature and archives. Visit BHL at https://www.biodiversitylibrary.org. 